\title{
Pendidikan Anti Hoaks Era 4.0 Perspektif Al-Qur'an
}

\author{
Akhmad Shunhaji \\ Pascasarjana Institut PTIQ Jakarta
}

akhmadshunhaji@ptiq.ac.id

\begin{abstract}
The development of communication technology in the Era of 4.0, gave rise to various kinds of hoax news that could be consumed by various groups of society. The emergence of such massive hoax news, the Al-Qur'an has described the impact and the solution. However, most Muslim communities are not aware of it. This paper explores the teachings of the Al-Qur'an about the possibility of hoax through various media developments and solutions. By using a descriptive qualitative approach, the author describes some of the hoax data that developed in Era of 4.0, did the assessment, and found a solutive step to address the hoax according to the Al-Qur'an. Hoax always occur in the history of human life. Hoax have a negative side that damages many parties. In fact, hoax can interfere with life stability. Therefore, hoax need to be addressed wisely. Anti-hoax education from the perspective of the Al-Qur'an is the maximum effort in addressing hoax through the development of teogenetic awareness. In this paper, it was found that teogenetic is the potential of individuals who have an important role in dealing with life problems, including addressing hoax problems wisely.
\end{abstract}

Keywords: Education, Hoax, Al-Qur'an perspective

\begin{abstract}
Abstrak
Perkembangan teknologi komunikasi di Era 4.0, memunculkan berbagai macam berita hoaks yang dapat dikonsumsi oleh berbagai kalangan masyarakat. Munculnya berita hoaks yang demikian masif, telah dipaparkan dampak serta penyelesaiannya di dalam Al-Qur'an. Tetapi, sebagian besar masyarakat muslim belum menyadarinya. Tulisan ini, menggali ajaran-ajaran Al-Qur'an tentang kemungkinan adanya hoaks melalui berbagai perkembangan media dan penyelesaiannya. Dengan menggunakan pendekatan kualitatif deskriptif, Penulis memaparkan sebagian data hoaks yang berkembang di Era 4.0, melakukan kajian, dan menemukan langkah solutif untuk menyikapi hoaks menurut Al-Qur'an. Hoaks selalu terjadi dalam sejarah kehidupaan maanusia. Hoaks memiliki sisi negative yang merusak banyak pihak. Bahkan, hoaks dapat mengganggu stabilitas kehidupan. Oleh karena itu, hoaks perlu disikapi secara bijak. Pendidikan anti hoaks perspektif Al-Qur'an merupakan upaya maksimal dalam menyikapi hoaks melalui pengembangan kesadaran theogenetis. Dalam tulisan ini, ditemukan bahwa theogenetis merupakan potensi individu yang memiliki peran penting dalam menghadapi permasalahan hidup, termasuk menyikapi permasalahan hoaks secara bijak.
\end{abstract}

Kata Kunci: Pendidikan, Hoaks, Perspektif Al-Qur'an 


\section{A. Pendahuluan}

Perkembangan teknologi semakin pesat, hingga menjadi bagian penting dalam kehidupan manusia. Teknologi membantu manusia memperingan melakukan banyak aktivitas. Teknologi komunikasi merupakan bagian dari perkembangan teknologi yang pesat itu. Pesatnya teknologi komunikasi diikuti perkembangnya situs berita. Menurut catatan Dewan Pers, awal tahun 2016 terdapat sekitar 43.000 situs di Indonesia yang mengklaim sebagai portal berita. Dari jumlah tersebut, yang sudah terverifikasi sebagai situs berita resmi tak sampai 300. Artinya terdapat setidaknya puluhan ribu situs yang berpotensi menyebarkan berita palsu di internet yang mesti diwaspadai.

Perkembangan teknologi komunikasi diikuti dengan perkembangan alat komunikasi yang dilengkapi dengan berbagai fitur multimedia. Fitur yang sering dicari oleh pengguna alat komunikasi dan semakin meningkat peminatnya adalah media sosial, seperti facebook, twitter, pinterest, path, instgram, dan sebagainya. Alat komunikasi yang menyediakan fiturfitur media sosial ini semakin dibutuhkan. Sebanyak 150 juta penduduk Indonesia menggunakan media sosial, dan masing-masing pengguna rata-rata memiliki 11 akun media social.

Tingginya penggunaan media sosial mengindikasikan tingginya potensi hoaks dalam berbagai pemberitaan. Kebanyakan hoaks tersebar melalui berita online. Bahkan, menurut data CNN Indonesia, 61\% pengguna media digital mempercayai konten online. Sedangkan, hoaks seringkali menjadi sumber kerusakan. Oleh karena itu, hoaks perlu diantisipasi. Cara yang mungkin efektif untuk mengantisipasi maraknya hoaks adalah dengan pendidikan anti hoaks.

Berpijak pada paparan di atas, maka mengkaji hoaks, dampak, dan solusinya di Era 4.0 menarik dilakukan. Tulisan ini bertujuan untuk melakukan analisis hoaks yang ada di Era 4.0 dan menemukan solusi terbaik menurut perspektif Al-Qur'an. Kesadaran terhadap pentingnya antisipasi terhadap hoaks dapat menyelematkan orang tersebut dari pengaruh buruk akibat hoaks. Bagi pelaku pembuat maupun penyebar konten hoaks, kesadaran terhadap bahaya hoaks diharapkan dapat membangkitkan kesadaran agar menghindari perilaku yang sama. Dengan demikian, hoaks akan jauh terkurangi, kalaupun tidak dapat dikatakan tidak ada sama sekali. Bagi obyek korban hoaks, tulisan ini diharapkan dapat memberikan kesadaran adanya bahaya hoaks sehingga dapat melakukan antisipasi aktif, bukan menjadi orang yang pasrah dan menyerah dengan keadaan. 


\section{B. Metode Penelitian/Metode Kajian}

Tulisan ini menggunakan pendekatan deskriptif kualitatif, yaitu penggambaran secara kualitatif fakta, data, atau obyek material yang bukan berupa rangkaian angka, melainkan ungkapan bahasa atau wacana melalui interpretasi yang tepat dan sistematis. Kajian utama adalah tafsir Al-Qur'an pada ayat-ayat yang terkait dengan hoaks di Era 4.0. Sedangkan, pemahaman terhadap era tersebut, penulis menggunakan buku Jagat Digital yang ditulis oleh Agus Sudibyo. Dalam tulisannya, Agus Sudibyo memberikan pemahaman bahwa Era 4.0 merupakan era ekonomi digital. Dalam pandangannya, Sudibyo memaparkan bahwa digitalisasi memiliki dua kecenderungan utama, yaitu sebagai media digital institusi sosial dan media sosial sebagai institusi bisnis yang motif utamanya adalah instrumentalisasi sekaligus komersialisasi . Kedua kecenderungan ini, dimaksudkan untuk memandang digitalisasi yang menjadi ciri Era 4.0 dalam perspektif keseimbangan. Keseimbangan dalam teori Sudibyo dimaksudkan bahwa dalam Era 4.0 perlu memandang digitalisasi dalam perspektif positive-optimistik dan perspektif ekonomi politik kritis.

\section{Hasil dan Pembahasan}

\section{Hoaks Di Era 4.0}

Istilah hoaks dalam KBBI diartikan sebagai berita bohong ${ }^{1}$. Definisi ini sejalan dengan definisi hoaks dalam Collins Dictionary. Dalam kamus tersebut, hoaks didefinisikan sebagai a trick in which someone tells people a lie ${ }^{2}$. Hoaks diartikan sebagai tipuan (trick), dimana seseorang memberi tahu orang lain tentang kebohongan atau sesuatu yang tidak sesuai dengan realitas. Hoaks di sini disamakan definisinya dengan trick yaitu an action that is intended to deceive someone ${ }^{3}$, tindakan yang dimaksudkan untuk menipu seseorang. Hoaks juga didefinisikan sebagai a plan to deceive someone (rencana untuk menipu seseorang), to deceive, especially by playing a trick on someone (menipu, terutama dengan mempermainkan seseorang), a trick or something else that is intended to deceive someone (sebuah trik atau hal lain yang dimaksudkan untuk menipu seseorang) ${ }^{4}$.

Dari beberapa literatur di atas, dapat dipahami bahwa hoax adalah informasi palsu, berita bohong, atau fakta yang diplintir atau direkayasa untuk tujuan lelucon hingga serius (politis). Hoaks juga dipahami sebagai berita palsu atau berita yang tidak benar sehingga menjurus pada kasus pencemaran nama baik. Barangkali, dapat dimasukkan dalam kategori

\footnotetext{
${ }^{1}$ https://kbbi.kemdikbud.go.id/entri/hoaks diakses tanggal 5 November 2019

${ }^{2}$ https://www.collinsdictionary.com/dictionary/english/hoax diakses pada tanggal 5 November 2019

3 https://www.collinsdictionary.com/dictionary/english/trick diakses pada tanggal 5 November 2019

4 https://dictionary.cambridge.org/dictionary/english/hoax diakses pada tanggal 5 November 2019
} 
berita bohong adalah pemberitaan yang tidak berdasarkan kenyataan atau kebenaran (nonfactual) untuk maksud tertentu.

Hoaks bertumbuhkembang seiring dengan meningkatnya popularitas media sosial. Robet Nares (1753-1829) menyebutkan istilah hoaks muncul pada akhir abad ke-18, dengan maksud menipu. Dalam konteks permainan tradisi April Mop, menipu digunakan untuk kepentingan humor. Dalam konteks politik, hoaks bertujuan untuk membuat lawan tenggelam dalam stigma yang menghancurkan posisinya ${ }^{5}$. Dengan demikian, hoaks dapat bertujuan untuk having fun atau humor dan alat propaganda dengan tujuan politis, misalnya melakukan pencitraan atau sebaliknya, memburukan citra seseorang atau kelompok.

Dalam pandangan Al-Qur'an, hoaks dalam arti berita bohong, terjadi sepanjang kehidupan sosial manusia. Bisa jadi, istilah hoaks digunakan sejak abad ke-18 tersebut. Namun, hoaks dalam arti berita bohong pernah terjadi jauh sebelum itu. Di dalam AlQur'an, diceritakan adanya saudara-saudara Nabi Yusuf yang memberikan kabar bohong kepada orang tuanya (QS. Yusuf [12]: 17).

Pada 2018, penduduk Indonesia sebanyak 263,9 juta jiwa ${ }^{6}$. Jumlah ini hampir sama dengan jumlah pelanggan kartu prabayar pada tahun 2018. Kementerian Komunikasi dan Informatika (Kominfo) mengumumkan bahwa hingga tanggal 30 April 2018, tercatat 254.792.159 pelanggan yang telah melakukan registrasi ulang ${ }^{7}$. Jumlah pelanggan ini, memang belum menggambarkan realitas pengguna aktif. Bisa jadi, ada pengguna yang belum mendaftarkan nomor kartunya, atau sebaliknya, sebagian orang yang pernah mendaftarkan kartunya kemudian membiarkannya menjadi tidak aktif. Mereka yang telah memiliki alat komunikasi cenderung ingin menggunakannya, tidak sekedar untuk berkomunikasi dengan orang lain. Mereka juga menggunakan alat komunikasinya untuk aktif di media sosial. Hasil temuan penelitian Digital a Round The World 2019 yang dipublikasikan pada tanggal 31 Januari 2019 menyebutkan perangkat mobile seperti smartphone dan tablet menjadi perangkat favorit yang digunakan 130 juta pengguna media sosial aktif Indonesia ${ }^{8}$.

\footnotetext{
${ }^{5}$ Ranang Aji SP, Opini public dan reproduksi hoax, dalam m.detik.com diakses pada 6 November 2019

${ }^{6}$ Dwi Hadya Jayani, Jumlah penduduk Indonesia 269 juta jiwa, terbesar keempat di dunia, dalam www.databoks.katadata.co.id, diakses pada 5 November 2019.

7 Daon, Inilah rincian jumlah pelanggan prabayar masing-masing operator, dalam www.kominfo.go.id, diakses pada 5 November 2019.

${ }^{8}$ Wahyunanda Kusuma Pertiwi, Separuh Penduduk Indonesia Sudah "Melek" Media Sosial dalam, https://tekno.kompas.com/read/2019/02/04/19140037/ separuh-penduduk-indonesia-sudah-melekmedia-sosial, diakses pada 6 November 2019.
} 
Menurut penelitian Center of Innovation Policy and Governance (CIPG), penetrasi internet dengan menggunakan teknologi informasi di Indonesia mencapai 51\%, merupakan yang tertinggi di Asia ${ }^{9}$. Perkembangan teknologi dalam berkomunikasi ini menggeser pola hidup masyarakat menjadi lebih melek teknologi ${ }^{10}$. Masyarakat menjadi lebih dekat dengan media digital. Media digital dengan memanfaatkan teknologi informasi menjadi gaya hidup baru. Sejak tahun 2015, pengguna media ini terus meningkat ${ }^{11}$.

Kehadiran media digital semakin menggeser media-media lain ${ }^{12}$. Media konvensional, seperti koran, majalah, dan sejenisnya sudah semakin jauh ditinggalkan. Media digital juga telah merubah kebutuhan masyarakat terhadap televisi konvensional. Masyarakat konsumen mulai lebih cenderung menyukai video streaming, tv online, maupun tv internet berlangganan. Dalam perubahan yang demikian, sebagian orang memanfaatkan media digital untuk tujuan ekonomi. Mereka sengaja mengunggah kontenkonten kontroversial, opini, bahkan cenderung pada berita palsu (hoax).

Baik media konvensional maupun media digital digunakan oleh orang-orang yang memanfaatkannya untuk berbagai macam keperluan, misalnya keperlun bisnis, pendidikan, kebudayaan, politik, hingga hanya sekedar bermain. Menurut Rudiantara, Menkominfo Kabinet Kerja, penggunaan internet dan media sosial sebagai sarana dalam kegiatan politik semakin meningkat dengan konten-konten hoaks dan provokatif ketika masa-masa Pilkada. Bahkan, hingga akhir Desember 2016, Kominfo telah memblokir setidaknya 773.097 situs negatif melalui Trust Postif ${ }^{13}$.

Hoaks menggunakan media digital mengalami pasang surut. Seperti yang telah dijelaskan pada paragraph sebelumnya. Penggunaan media konvensional maupun media digital cenderung mengalami kenaikan saat pemilu, baik pilkada, pileg, maupun pilpres. Tercatat sebanyak 486 hoax diidentifikasi oleh Kementerian Kominfo melalui media digital selama April 2019, dan 209 diantaranya hoaks berasal dari kategori politik ${ }^{14}$.

\footnotetext{
${ }^{9}$ Rappler.com, Gambaran pemanfaatan teknologi informasi di Indonesia, dalam www.rappler.com, diakses pada 5 November 2019.

${ }^{10}$ Rudi Ahmad Suryadi dan Aguslani Mushlih, Desain dan perencanaan pembelajaran, Jakarta: Deepublisher, 2019, h. 52

${ }^{11}$ Muhammad Fadhilah Zein, Panduan Menggunakan Media Sosial untuk Generasi Emas Milenial, leanpu.com, h. 25

${ }^{12}$ Rahma Sugihartati, Perkembangan masyarakat informasi \& teori sosial kontemporer, Jakarta: Prenadamediagrup, 2014, h. 87

${ }^{13}$ Diandra, asal-mula situs hoax berkembang di Indonesia, dalam https://www.kominfo.go.id/ content/detail /8629/asal- mula-situs- hoax-berkembang-di-indonesia /0 /sorotan_media diakses pada tanggal6 November 2019

14 Tsarina Maharani, April 2019, 209 terkait politik, dalam https://news.detik.com/berita/d4532182/kominfo-identifikasi-486-hoax-sepanjang-april-2019-209-terkait-politik diakses pada 11 November 2019
} 
Berita-berita di media digital memang tidak semua salah, tetapi juga tidak ada jaminan seluruhnya benar. Banyak alasan seseorang ingin mengakses dan menyebarkan informasi ataupun berita yang diperoleh melalui media digital. Dari beberapa sumber yang penulis amati, sekurang-kurangnya ditemukan alasan mendasar seseorang tertarik dengan suatu berita. Alasan tersebut adalah karena berita yang diperoleh berasal dari orang yang dipercaya. Analisis penulis ini, sejalan dengan data yang disampaikan oleh Kadiv Humas Polri Irjen Setyo Wastito. Menurut Setyo, alasan-alasan orang menyebarkan hoax, pertama 48 persen berita itu berasal dari orang yang dipercaya, alasan kedua 31 persen orang merasa informasi itu bermanfaat, alasan ke tiga, 18 persen mengira bahwa berita itu benar dan yang ke empat 3 persen merasa ingin jadi yang pertama sebarkan berita itu ${ }^{15}$.

Realitas yang dirasakan oleh banyak pengguna, media sosial tidak selalu menghadirkan berita-berita yang serius. Media sosial juga menghadirkan kegembiraan, gairah dan kemudahan baru bagi masyarakat penggunanya. Suatu mode interaksi sosial baru telah hadir di tengah-tengah mereka yang terkadang membuat mereka asyik mengikuti permainannya hingga menggunakannya dalam percakapan-percakapan yang cenderung pada pembicaraan yang tidak seratus persen benar.

Menurut Danarka Sasongko, penyebab maraknya hoaks di media sosial ada empat hal pokok. Pertama, literasi publik terhadap pesan-pesan di media sosial masih rendah. Hal itulah yang menyebabkan berita-berita palsu atau hoax banyak dibagikan oleh masyarakat di media-media sosial pribadinya. Kedua, dunia media sosial bagi masyarakat Indonesia adalah hal yang baru yang menyenangkan. Ketiga, emosi masyarakat disulut dengan ego pemilihan kepala daerah atau pemilihan umum. Keempat, kultur politik masyarakat belum matang ${ }^{16}$.

Dari uraian di atas, penulis menganalisis adanya berita, pembicaraan, percakapan yang muncul dalam media digital. Pertama, informasi dan percakapan yang disajikan merupakan informasi yang sahih dan mencerahkan. Percakapan yang terjadi adalah percakapan yang bermanfaat baik. Kedua, informasi ataupun percakapan dalam media digital mengandung unsur hoaks, yang berarti tidak sahih. Kalimat tidak sahih ini bisa dianalisis dari judul berbeda dengan isi berita, konten berita disajikan dengan narasi konteks yang salah, konten berita dipelintir untuk menjelekkan orang lain, mencatut nama

\footnotetext{
15 Ibnu Hariyanto, Polri Beberkan Penyebab Hoax Bisa Tersebar Luas di Masyarakat, dalam https://news.detik.com/berita/d-4257442/polri-beberkan-penyebab-hoax-bisa-tersebar-luas-di-masyarakat diakses pada 8 November 2019

16 Angelina Anjar Sawitri, 4 penyebab hoax mudah viral di media sosial, dalam https://nasional.tempo.co/read/838621/4-penyebab-hoax-mudah-viral-di-media-sosial/full\&view=ok, diunduh pada 12 November 2019
} 
tokoh publik dalam pemberitaan yang tidak sesuai, mengubah konten benar yang sudah ada, dan konten memang benar-benar palsu.

Telah disebutkan di atas, bahwa penggunaan media digital dapat membawa kebaikan dan ketidakbaikan karena hoaks. Apapun itu, ada hal yang sering tidak disadari oleh pengguna media digital, yaitu ekonomi politik data pengguna. Semua orang yang menggunakan media digital adalah orang-orang yang telah merelakan diri menyampaikan datanya kepada pihak lain ${ }^{17}$. Mereka yang berkepentingan terus mendorong agar para pengguna media digital terus menambah jam penggunaannya. Dari sini, ada kemungkinan penyebaran hoaks adalah upaya yang memang dipelihara agar pengguna media digital semakin merasa tertarik untuk terus meningkatkan penggunaanya.

\section{Isyarat Al-Qur'an Dalam Pendidikan Anti Hoaks}

Pendidikan merupakan upaya untuk membuat manusia semakin dewasa cara berfikir, bertindak, dan berkeyakinan ${ }^{18}$. Pendidikan perlu dilakukan sepanjang hayat, karena cara berfikir, bertindak, bahkan cara berkeyakinan seseorang sangat mungkin fluktuatif karena pengaruh keadaan.

Saat ini, Indonesia memasuki era 4.0, sama dengan negara-negara lainnya. Era ini ditandai dengan trend otomatisasi, komputerisasi, digitalisasi, dan pertukaran data terkini dalam teknologi industri ${ }^{19}$. Di era ini, semua orang seolah-olah 'dipaksa' untuk melek teknologi. Percakapan, informasi, dan berita lebih banyak disajikan melalui media digital. Terjadi disrupsi (perubahan secara fundamental) dalam banyak hal dikehidupan.

Dalam kehidupan yang demikian, hoaks mewarnai dibanyak konten pemberitaan dan sejenisnya. Motif munculnya hoaks beragam, seperti ideologi, politik, ekonomi, hingga sekedar bercanda. Hoaks yang dipahami sebagai berita bohong terdapat pembahasannya di dalam Al-Qur'an. Memang, dalam sejarah perjalanan Rasulullah SAW pernah terjadi masalah besar terkait dengan hoaks yang menimpa istri Beliau, sayyidatina Aisyah ra. Hoaks ini diyakini oleh para sejarawan, sebagai peristiwa yang sengaja dihembuskan oleh kaum Munafik.

Istilah berita bohong (hoax) dalam Al-Qur'an bisa diidentifikasi dari pengertian kata (الافلك) al-Ifk yang berarti keterbalikan (seperti gempa yang membalikkan negeri), tetapi yang dimaksud di sini ialah sebuah kebohongan besar, karena kebohongan adalah

\footnotetext{
${ }^{17}$ Sudibyo, Jagat digital, ..., h. 7

${ }^{18}$ Akhmad shunhaji, implementasi pendidikan agama di sekolah Katolik Kota Blitar dan dampaknya terhadap interaksi sosial, Yogyakarta: Aynat Publishing, 2017, h. 36.

${ }^{19}$ Forkomsi FEB UGM, Revolusi Industri 4.0I, Sukbumi, Jawa Barat, CV Jejak, 2019, h. 172
} 
pemutarbalikan fakta ${ }^{20}$. Sedangkan munculnya hoax (sebuah kebohongan) disebabkan oleh orang-orang pem- bangkang. Dalam hal ini, Al-Qur'an mengistilahkannya dengan'usbah (عصبة). Kata 'usbah diambil dari kata 'ashaba (عصب) yang pada mulanya berarti mengikat dengan keras. Dari asal kata ini lahir kata muta'ashshib (متعصّب) yaknifanatik. Kata ini dipahami dalam arti kelompok yang terjalin kuat oleh satu ide, dalam hal ini menebarkan isu negatif, untuk mencemarkan nama baik ${ }^{21}$.

Sinyalemen yang ada, berdasarkan fakta sejarah bahwa orang-orang Munafik telah gagal menyulut sentimen kesukuan ditengah para shahabat Rasulullah shallallahu 'alaihi wa sallam. Mereka tidak lantas putus asa. Mereka terus mencari upaya yang meresahkan untuk mengurangi kekuatan kaum Muslimin. Mereka memanfaatkan insiden lain untuk menyebar racun di tengah kaum Muslimin. Peristiwa ini terkenal dengan haditsul ifki (berita dusta).

Kisah ini bermula ketika Aisyah ra, istri Nabi Muhammad SAW kehilangan kalungnya $^{22}$ saat perjalanan menuju Madinah pasca peperangan Bani Musthaliq pada tahun ke $5 \mathrm{H}$. Pada saat istirahat, Aisyah ra keluar dari haudij/sekedupnya (semacam tandu yang berada di atas punggung unta) untuk suatu keperluan. Ketika kembali ke sekedupnya, Beliau merasa kehilangan kalung. Akhirnya, Beliau ra keluar lagi untuk mencarinya. Saat kembali untuk yang kedua kali inilah Beliau ra telah ditinggal oleh rombongan.

Para shahabat yang menaikkan sekedup ke punggung unta tidak menyadari bahwa Aisyah ra tidak ada di dalamnya karena dia masih ringan. Beliau ra merasa gelisah karena ditinggal rombongan. Namun, Beliau tetap menunggu di tempat semula, dengan harapan rombongan Rasulullah SAW segera menyadari ketiadaannya dan kembali mencarinya di tempat mereka istirahat. Akan tetapi, rombongan yang ditunggu tidak kunjung datang, sampai akhirnya Aisyah ra tertidur.

Sahabat yang bertugas membawa minum Rasulullah SAW dalam setiap peperangan dan juga tim penyapu di bagian belakang pasukan melewati tempat Aisyah tertidur. Sahabat Rasulullah SAW itu bernama Shafwan bin Al-Mu'aththal As-Sulami AdzDzakwani ra lewat di tempat itu dan mengenali 'Aisyah ra. Shafwan ra pernah melihat Aisyah ra saat sebelum hijab diwajibkan. Di sinilah, awal cerita yang dimanfaatkan oleh kaum munafik untuk menyebarkan fitnah.

\footnotetext{
${ }^{20}$ Idnan A. Idris, Klarifikasi Al-Quran Atas Berita Hoaks, Jakarta: PT Elex Media komputindo, 2018, h. 18

${ }^{21}$ M. Quraish Shihab, Tafsir Al-Misbah Pesan, Kesan dan Keserasian Al-Quran, vol. 9 , Jakarta: Lentera Hati, 2002, h. 296.

${ }^{22}$ Idris, Klarifikasi Al-Quran Atas Berita Hoaks, .., , 2018, h. 18
} 
Peristiwa ini dimanfaatkan oleh kaum munafik. Mereka membubuhi kisah ini dengan berbagai cerita bohong. Diantara yang sangat berantusias menyebarkan cerita bohong dan keji itu adalah 'Abdullah bin Ubay Ibnu Salul. Cerita bohong itu menyebar dengan cepat, dari mulut ke mulut, sehingga ada beberapa shahabat yang terfitnah dan tanpa disadari ikut andil dalam menyebarkan berita ini. Mereka adalah Misthah bin Utsatsah (sepupu Abu Bakr Ash-Shiddiq radhiyallahu 'anhu), Hassan bin Tsabit dan Hamnah bintu Jahsy radhiyallahu anhum.

Rasulullah SAW sedih dengan berita yang tersebar. Beliau sedih bukan karena meragukan kesetiaan istri Beliau SAW. Nabi SAW percaya Aisyah ra dan Shafwan ra tidak seperti yang digunjingkan. Berita yang sangat menyakiti hati Rasulullah SAW ini memantik kemarahan para shahabat dan hampir saja menyulut pertikaian diantara kaum Muslimin.

Sebulan penuh, Aisyah ra merasakan kepedihan dan juga Rasulullah SAW akibat ulah orang-orang munafik ini. Kesedihan Beliau berakhir ketika Allah SWT menurunkan sepuluh ayat Al-Qur'an, surat An-Nûr [24]: 11-20, perihal berita dusta ini. Beberapa ayat pada surat tersebut menjelaskan sebagai berikut:

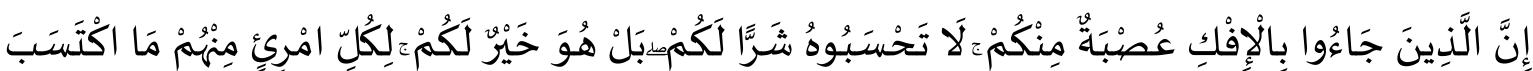

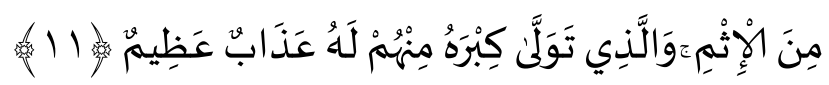

Sesungguhnya orang-orang yang membawa berita bohong itu adalah dari golongan kamu juga. Janganlah kamu kira bahwa berita bohong itu buruk bagi kamu bahkan ia adalah baik bagi kamu, tiap-tiap orang dari mereka mendapat balasan dari dosa yang dikerjakannya. Dan siapa di antara mereka yang mengambil bagian terbesar dalam penyiaran berita bohong itu, maka baginya azab yang besar.

Orang yang membuat ataupun menyebarkan hoaks, biasanya melakukannya dengan sengaja dan diniatkan untuk maksud tertentu. Pada QS. An-Nûr [24]: 11, menggunakan kalimat iktasaba (اكتسب), untuk menyebut orang yang mengambil bagian terciptanya hoaks. Iktasaba menunjukkan bahwa penyebaran isu itu dilakukan dengan sungguhsungguh. Ini bukan saja dipahami dari kata kasaba yang mengandung makna usaha, tetapi juga dari tambahan huruf $t a{ }^{\prime}{ }^{\prime}$ ) dalam kata tersebut ${ }^{23}$. Kata (كبره) kibrahu terambil dari

\footnotetext{
${ }^{23}$ Shihab, Tafsir Al-Misbah Pesan, Kesan dan Keserasian Al-Quran, ... h.297.
} 
kata (كبر) kibr atau kubr yang digunakan dalam arti yang terbanyak dan tersebar. Yang dimaksud disini adalah yang paling banyak dalam menyebarkan berita hoaks ${ }^{24}$.

Al-Qur'an mengajarkan agar seseorang memiliki tingkat berfikir yang tinggi (high order thinking skill). Setiap orang diharapkan memiliki kemampuan berpikir kritis, logis, reflektif, metakognitif, dan berpikir kreatif. Seorang yang memiliki tingkat berfikir tinggi akan kritis terhadap berita yang diterima. Hal penting yang perlu dilakukan adalah konfirmasi ulang (tabayyun), seperti yang dianjurkan oleh QS. Al-Hujurât [49]: 6,

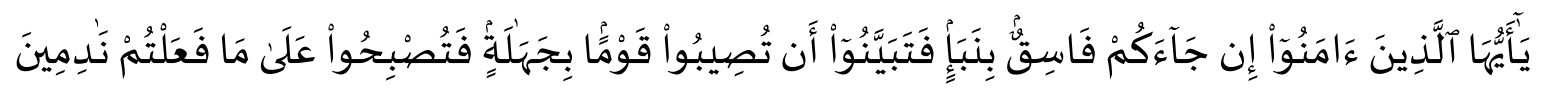

Hai orang-orang yang beriman, jika datang kepadamu orang fasik membawa suatu berita, maka periksalah dengan teliti agar kamu tidak menimpakan suatu musibah kepada suatu kaum tanpa mengetahui keadaannya yang menyebabkan kamu menyesal atas perbuatanmu itu

Kalimat fatabayyanû mengisyaratkan perintah berpikir kritis, logis, dan reflektif. Dalam Tafsir Jalalain, kalimat tersebut dibaca fatatsabbatû berasal dari lafal ats-Tsabât, artinya telitilah terlebih dahulu kebenarannya. Perintah meneliti ini, disebabkan adanya dampak negatif dari hoaks ${ }^{25}$.

Hoaks sangat merugikan orang lain. Dampak yang ditimbulkan dari hoaks dapat merusak tatanan, persaudaraan, keuntungan bisnis, hingga akidah. Karena itulah, para pembuat dan penyebar hoaks diperingatkan dengan ancaman berat, dalam Al-Qur'an. Hal ini sejalan dengan penegasan QS. An-Nûr [24]: 19, sebagai berikut:

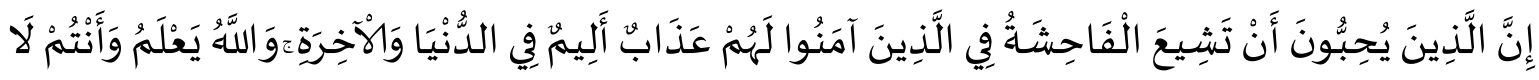

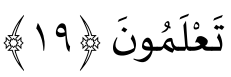

Sesungguhnya orang-orang yang ingin agar (berita) perbuatan yang amat keji itu tersiar di kalangan orang-orang yang beriman, bagi mereka azab yang pedih di dunia dan di akhirat dan Allâh mengetahui, sedang, kamu tidak mengetahui.

Kerugian yang ditimbulkan akibat hoaks pernah menimpa perusahaan yang bergerak pada media sosial. Hal seperti ini pernah dialami oleh perusahaan facebook yang sempat kehilangan nilai pasar US\$130 miliar (Rp 1.878 triliun) pada Rabu, 25 Juli 2018.

\footnotetext{
${ }^{24}$ Shihab, Tafsir Al-Misbah Pesan, Kesan dan Keserasian Al-Quran, ... h.298.

${ }^{25}$ Jalaludin Muhammad Ibn Ahmad Ibn Muhammad Al-Mahalli dan Jalaluddin Abdurahman Ibn Abu Bakar As Sayuti, Tafsir Al-Jalalain, Jakarta: Dar Al-Kutub Al-Islamiyah, 2011, h. 443
} 
Kerugian ini disebabkan antara lain oleh isu kebocoran data dan berita hoaks tentang perusahaan tersebut ${ }^{26}$. Kerugian yang demikian dapat menimpa siapapun sebagai korban hoaks. Oleh sebab itu, seseorang perlu mendidik dirinya untuk menghadapi hoaks yang selalu mengancam.

Al-Qur'an mengajarkan agar seseorang mengembangkan potensi dasarnya, untuk mampu menikmati hidup. Setiap orang memiliki dasar biogenetis, sosiogenetis, dan teogenetis. Agar hidup dapat dinikmati oleh seseorang, maka ketiganya perlu dikembangkan secara normal dan saling melengkapi. Namun, dalam konteks menghadapi dan menyikapi hoaks, seseorang perlu lebih mengembangkan potensi teogenetisnya. Potensi teogenetis merupakan kebutuhan seseorang kepada Dzat Yang Maha Kuasa ${ }^{27}$. Sebagai potensi dasar, maka teogenentis sejatinya dimiliki oleh setiap individu ${ }^{28}$. Teogenetis merupakan kebutuhan dasar manusia untuk merealisasikan norma-norma agamanya. Kebutuhan dasar inilah yang mendorong pemiliknya berinteraksi dengan orang lain dan lingkungan. Realisasi norma-norma agama dalam jiwa seseorang, dapat mendorong pemiliknya lebih bertindak bijak.

Hoaks Era 4.0 seringkali berupa berita yang tidak mudah dikontrol oleh obyek penerima hoaks tersebut. Bahkan, seringkali ketika sebuah berita hoaks sudah terlempar di media publik, lebih banyak orang yang menjadi korban karena tertarik ikut menyebarluaskannya. Mereka yang ikut menyebarkan hoaks bahkan terancam undangundang berlapis. Mereka mungkin dapat terjerat dengan Undang-Undang No 11 Tahun 2008 Tentang informasi dan transaksi elektronik (ITE), Undang-Undang No 40 Tahun 2008 tentang penghapusan diskriminasi ras dan etnis, serta tindakan ketika hoaks tersebut menjadi ujaran kebencian yang menyebabkan konflik sosial ${ }^{29}$. Al-Qur'an mengisyaratkan, ketika seseorang menghadapi hoaks, agar menyandarkan dirinya kepada Tuhan. Hal ini tergambar dalam QS. An-Nûr [24]: $20^{30}$.

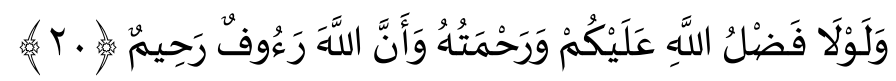

\footnotetext{
${ }^{26}$ Ester Christrine Natalia, Saham Anjlok, Kapitalisasi Pasar Facebook Menguap Rp 1.878 T, dalam https://www.cnbcindonesia.com/tech/20180726110540-37-25453/saham-anjlok-kapitalisasi-pasar-facebookmenguap-rp-1878-t, diakses pada 5 November 2019

${ }^{27}$ Af Idah Salmah (ed), teologi Islam Terapan, Jakarta: Tiga Serangkat, 2003, h. 52

${ }^{28}$ Seorang atheis, yang tidak mempercayai adanya Tuhan, juga memiliki potensi teogenetis ini. Buktinya, ketika dia sedang tertimpa musibah yang sangat menyusahkannya, dia akan berharap kepada Dzat yang dianggap melebihi darinya.

29 Diandra, "Penebar hoax bisa dijerat segudang pasal" dalam kominfo. go.id diakses pada tanggal 20 November 2019

${ }^{30}$ Keterangan yang hampir sama juga dijelaskan dalam QS. An-Nûr/ 24: 14
} 
Dan sekiranya bukan karena karunia Allah dan rahmat-Nya kepada kamu semua, dan Allah Maha Penyantun dan Maha Penyayang, (niscaya kamu akan ditimpa azab yang besar).

Dalam konteks cerita hoaks terhadap 'Aisyah ra, telah dijelaskan oleh Allah SWT dengan penegasan membenarkan Aisyah ra. Ayat-ayat di atas, memperjelas posisi Aisyah ra. Penetapan Allah SWT yang menyatakan kebohongan berita yang beredar, memberikan penjelasan yang sangat gamblang. Dengan turunnya ayat ini, maka permasalahan ini pun menjadi jelas. Rasulullah SAW dan Ummul Mu'minin Aisyah ra merasa lega. Begitu juga yang dirasakan oleh kaum Muslimin.

Hoaks dalam arti berita bohong juga pernah disampaikan oleh saudara-saudara Nabi Yusuf AS kepada ayah mereka, yaitu Nabi Ya'qub AS. Mereka menyampaikan berita tentang meninggalnya Yusuf kecil. Berita yang mereka sampaikan bahwa Yusuf telah mati dimakan serigala, saat mereka bermain dan meninggalkan Yusuf. Dalam QS. Yusuf [12]: 17, Allah SWT berfirman:

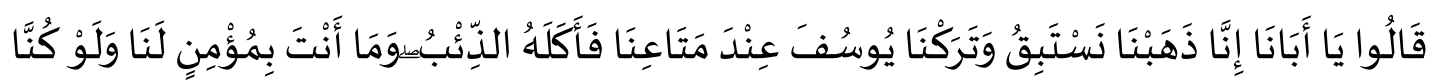

Mereka berkata: "Wahai ayah kami, sesungguhnya kami pergi berlomba-lomba dan kami tinggalkan Yusuf di dekat barang-barang kami, lalu dia dimakan serigala; dan kamu sekali-kali tidak akan percaya kepada kami, sekalipun kami adalah orang-orang yang benar"

Menurut imam Jalalain, Saudara-saudara Nabi Yusuf AS berkata dengan menggunakan alibi yang telah disampaikan oleh ayahnya yaitu kekhawatiran dimakan oleh serigala. Mereka membuat cerita dengan mengatakan bahwa mereka sedang pergi berlomba-lomba memanah. Sedangkan Yusuf kecil ditinggalkan untuk menunggu dekat barang-barang mereka. Di situlah kemudian mereka menyampaikan bahwa Yusuf telah dimakan oleh serigala. Hanya saja, kalimat kebohongan mereka diikuti dengan keraguan. Mereka mengucapkan kalimat Engkau (Nabi Ya'qub AS, ayah mereka) sekali-kali tidak akan mempercayai kami sekali pun kami adalah orang-orang yang benar. Pernyataan ini justru menegaskan kebohongan mereka. Karena itu, imam Jalalain menuliskan dengan kalimatnya "pasti engkau akan menuduh kami dengan tuduhan yang bukan-bukan 
sehubungan dengan perihal Yusuf ini karena kecintaanmu terhadapnya. Mengapa sampai sedemikian buruknya persangkaanmu terhadap diri kami?"31.

Beberapa literatur di atas, menunjukkan bahwa hoaks dalam arti berita bohong membuat keresahan. Dalam kontek cerita hoaks yang menimpa Aisyah ra, kaum Muslim merasakan keresahan mendalam, terlebih Rasulullah SAW dan Aisyah ra. Dalam konteks cerita Nabi Yusuf AS, ayahanda Beliau Nabi Ya'qub AS merasakan keresahan yang mendalam juga.

Potensi teogenetis juga ditampakkan oleh Nabi Ya'qub ketika menghadapi hoaks yang disampaikan oleh saudara-saudranya Yusuf kecil. Hal ini dijelaskan dalam QS. Yusuf [12]: 18, sebagai berikut:
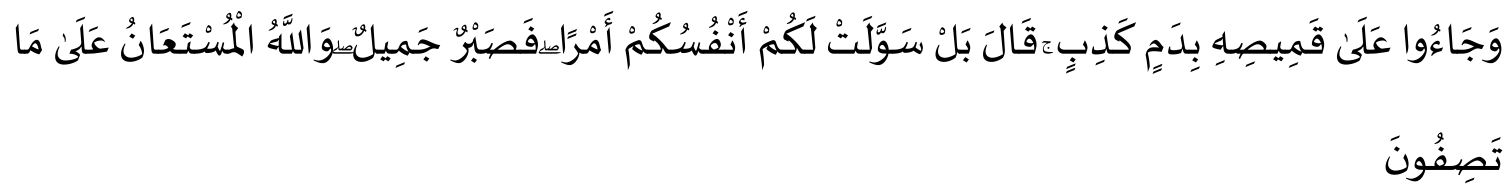

Mereka datang membawa baju gamisnya (yang berlumuran) dengan darah palsu. Ya'qub berkata: "Sebenarnya dirimu sendirilah yang memandang baik perbuatan (yang buruk) itu; maka kesabaran yang baik itulah (kesabaranku). Dan Allah sajalah yang dimohon pertolongan-Nya terhadap apa yang kamu ceritakan"

Tipuan yang dilakukan oleh saudara-saudara Yusuf kecil jelas diketahui oleh ayah mereka. Dalam Tafsir Jalalain, disebutkan bahwa Mereka datang membawa baju gamis nabi Yusuf AS yang berlumuran dengan darah palsu. Mereka melumurkan darah kambing yang disembelih tetapi mereka lupa merobek-robeknya. Nabi Ya'qub AS berkata "kesabaran yang baik itulah kesabaranku" yaitu kesabaran yang tidak disertai rasa kaget dan gelisah ${ }^{32}$.

Penjelasan yang menggambarkan menonjolnya potensi teogenetis adalah akhir ayat ini. Dalam akhir ayat, Allah SWT memberikan penekanan bahwa Allah SWT sajalah yang paling tepat untuk diminta pertolongan-Nya.

Hoaks dalam paparan di atas, merupakan berita kebohongan seratus persen, kebohongan yang sesungguhnya. Dalam Al-Qur'an melarang kebohongan di bawah itu, yaitu kabar kebohongan di bawah seratus persen yang disebut dengan istilah dhan (perasangka). Hal ini ditegaskan oleh QS. Al-Hujurât [49]: 12, sebagai berikut:

\footnotetext{
${ }^{31}$ Al-Mahalli, Tafsir Al-Jalalain, ..., h. 312

32 Jalaludin Muhammad Ibn Ahmad Ibn Muhammad Al-Mahalli dan Jalaluddin Abdurahman Ibn Abu Bakar As Sayuti, Tafsir Al-Jalalain, ..., h. 312
} 


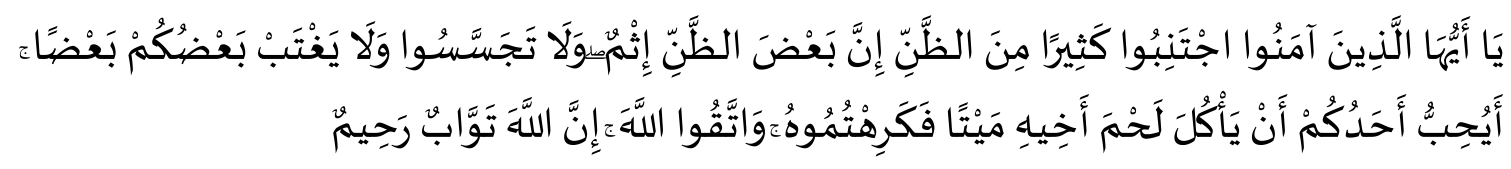

Hai orang-orang yang beriman, jauhilah kebanyakan purba-sangka (kecurigaan), karena sebagian dari purba-sangka itu dosa. Dan janganlah mencari-cari keburukan orang dan janganlah menggunjingkan satu sama lain. Adakah seorang diantara kamu yang suka memakan daging saudaranya yang sudah mati? Maka tentulah kamu merasa jijik kepadanya. Dan bertakwalah kepada Allah. Sesungguhnya Allah Maha Penerima Taubat lagi Maha Penyayang.

Perasangka jika dibuat dalam kategori berita, menjadi berita yang tidak sesuai dengan fakta. Ketidaksesuaian berita ini kurang dari seratus persen. Artinya, berita dalam bentuk dhan, syak, maupun wahm, tidak seratus persen betul dan tidak seratus persen salah. Dalam konteks berita yang demikian, dilarang dalam Al-Qur'an. Dengan demikian, sikap Al-Qur'an jelas bahwa semua berita yang tidak sesuai dengan realita atau fakta yang mendukung adalah berita hoaks. Hukum berita hoaks yang demikian dalam Al-Qur'an telah jelas dilarangnya.

\section{Penutup}

Dari paparan tentang pendidikan anti hoaks di Era 4.0 perspektif Al-Qur'an, dapat disimpulkan sebagai berikut: Pertama, hoaks merupakan berita kebohongan dan kebohongan itu memasukkan pada ukuran sedikit di bawah kebenaran. Berita seperti ini terjadi dalam sejarah hidup manusia. Kebohongan pernah terjadi dalam sejarah Nabi Yusuf AS, sejarah Nabi Muhammad SAW, hingga Era 4.0.

Kedua, hoaks jelas hukumnya dilarang oleh Al-Qur'an. Hoaks ini memasukkan hoaks di Era 4.0 dalam bentuk kemasan media digital apapun. Media digital di Era 4.0 sebagian digunakan untuk memberikan akses kebebasan publik dan sekaligus sebagai media politik ekonomi. Sebagai media politik ekonomi, kemungkinan memunculkan hoaks sangat rentan.

Ketiga, setiap individu berpotensi menghadapi hoaks. Setiap individu dikaruniakan potensi teogenetis untuk menghadapi secara bijak setiap hoaks yang berhubungan pada dirinya, baik langsung maupun tidak langsung. Oleh karena itu, mengembangkan potensi teogenetis secara maksimal, disertai dengan pemenuhan terhadap pengembangan potensi dasar yang lain, merupakan tindakan tepat dalam menghadapi hoaks di Era 4.0. 


\section{E. Daftar Pustaka}

Al-Mahalli, Jalaludin Muhammad Ibn Ahmad Ibn Muhammad dan Jalaluddin Abdurahman Ibn Abu Bakar As Sayuti, Tafsir Al-Jalalain, Jakarta: Dar Al-Kutub Al-Islamiyah, 2011.

Daon, Inilah rincian jumlah pelanggan prabayar masing-masing operator, dalam www.kominfo.go.id, diakses pada 5 November 2019.

Diandra, asal-mula situs hoax berkembang di Indonesia, dalam https://www.kominfo.go.id/ content/detail /8629/asal- mula-situs- hoaxberkembang-di-indonesia /0 /sorotan_media diakses pada tanggal6 November 2019

Diandra, Penebar hoax bisa dijerat segudang pasal dalam kominfo. go. id diakses pada tanggal 20 November 2019

Ester Christrine Natalia, Saham Anjlok, Kapitalisasi Pasar Facebook Menguap Rp 1.878 T, dalam https://www.cnbcindonesia.com/tech/20180726110540-37-25453/sahamanjlok-kapitalisasi-pasar- facebook-menguap-rp-1878-t, diakses pada 5 November 2019

Forkomsi FEB UGM, Revolusi Industri 4.0I, Sukbumi, Jawa Barat, CV Jejak, 2019.

Hariyanto, Ibnu, Polri Beberkan Penyebab Hoax Bisa Tersebar Luas di Masyarakat, dalam https://news.detik.com/berita/d-4257442/polri-beberkan-penyebab-hoaxbisa-tersebar-luas-di-masyarakat diakses pada 8 November 2019

https://dictionary.cambridge.org/dictionary/english/hoax diakses pada tanggal 5 November 2019

https://kbbi.kemdikbud.go.id/entri/hoaks diakses tanggal 5 November 2019

https://www.collinsdictionary.com/dictionary/english/hoax diakses pada tanggal 5 November 2019

Idris, Idnan A., Klarifikasi Al-Quran Atas Berita Hoaks, Jakarta: PT Elex Media komputindo, 2018.

Jayani, Dwi Hadya, Jumlah penduduk Indonesia 269 juta jiwa, terbesar keempat di dunia, dalam www.databoks.katadata.co.id, diakses pada 5 November 2019.

Juditha, Christiany, "Interaksi komunikasi hoax di media sosial serta antisipasinya" dalam Jurnal Pekonmas, Vol. 3 No.1, April 2018.

Lies, Ute, dkk, Komunikasi budaya dan dokumentasi kontemporer, Bandung: Unpad Press, 2019. 
Maharani, Tsarina, April 2019, 209 terkait politik, dalam https://news.detik.com/berita/d4532182/kominfo-identifikasi-486-hoax-sepanjang-april-2019-209-terkait-politik diakses pada 11 November 2019

Pertiwi, Wahyunanda Kusuma, Separuh Penduduk Indonesia Sudah "Melek" Media Sosial dalam, https://tekno.kompas.com/read/2019/02/04/19140037/ separuh-pendudukindonesia-sudah-melek-media-sosial, diakses pada 6 November 2019

Pertiwi, Wahyunanda Kusuma, Separuh Penduduk Indonesia Sudah "Melek" Media Sosial dalam, https://tekno.kompas.com/read/2019/02/04/19140037/ separuh-pendudukindonesia-sudah-melek-media-sosial, diakses pada 6 November 2019.

Ranang Aji SP, Opini public dan reproduksi hoax, dalam m.detik.com diakses pada 6 November 2019

Rappler.com, Gambaran pemanfaatan teknologi informasi di Indonesia, dalam www.rappler.com, diakses pada 5 November 2019.

Salmah, Af Idah (ed), teologi Islam Terapan, Jakarta: Tiga Serangkat, 2003.

Santhika, Eka, Alasan hoax mudah tersebar di IndonesiaI, dalam https://www.cnnindonesia.com/teknologi/20171019112305-185-249426/alasanhoax-mudah-tersebar-di-indonesia, diakses pada 12 November 2019.

Sawitri, Angelina Anjar, 4 penyebab hoax mudah viral di media sosial, dalam https://nasional.tempo.co/read/838621/4-penyebab-hoax-mudah-viral-di-mediasosial/full\&view=ok, diunduh pada 12 November 2019

Setianto, Eko H. dan Ali Zaki, Tampil beda dengan perangkat digital, Jakarta: PT Elex Media Komputindo, 2008.

Shihab, M. Quraish, Tafsir Al-Misbah Pesan, Kesan dan Keserasian Al-Quran, vol. 9 , Jakarta: Lentera Hati, 2002.

Shunhaji, Akhmad, implementasi pendidikan agama di sekolah Katolik Kota Blitar dan dampaknya terhadap interaksi sosial, Yogyakarta: Aynat Publishing, 2017.

Sudibyo, Agus, Jagat digital, Jakarta: KPG, 2019.

Sugihartati, Rahma, Perkembangan masyarakat informasi \& teori sosial kontemporer, Jakarta: Prenadamediagrup, 2014.

Suryadi, Rudi Ahmad dan Aguslani Mushlih, Desain dan perencanaan pembelajaran, Jakarta: Deepublisher, 2019.

Wibowo, Wahyu, Cara cerdas menulis artikel ilmiah, Jakarta: Penerbit Kompas, 2011.

Yunita, Ini Cara Mengatasi Berita “Hoax” di Dunia Maya, dalam kominfo.go.id, diakses pada 6 November 2019. 
Zein, Muhammad Fadhilah, Panduan Menggunakan Media Sosial untuk Generasi Emas Milenial, leanpu.com. 
